\title{
HERBAL FOLK MEDICINE OF CHITRADURGA TALUK, KARNATAKA
}

\author{
Manikanta.G.S, Dr.Somashekhar.G, Malammanavar \\ Department of P.G Studies and research in applied botany \\ Janasahydri, Kuvempu University Shankarghatta - 577451 \\ Shivamogga Karnataka
}

\begin{abstract}
A survey has been carried out in chitradurga taluk karnataka to meet the people who live in rural area away from the hospitals for documenting their knowledge about the usage of plant against many disease like chestpain, backpain, piles, fertility, asthama, Jaundice, burning urination, diabeties, fever, heart disease, tuberculosis, and many other deadly disease the presentation bring out 41 plant species against dentalgia.
\end{abstract}

Key words - Herbal folk medicine, indigenous medicine, Karnataka medicinal plants ethnomedicine, ruralherbalists.

\section{INTRODUCTION}

India has one of the worlds richest medicinal plant heritages the wealth is not only in terms of the number of unique species documented, but also in terms of the tremendous depth of traditional knowledge for the use of human and livestocks health and also,for agriculture plant have been used in traditional medicine for thousands of years. The knowledge of medicinal plants has been accumulated in the course of many centuries based on different medicinal plants such as Ayurveda,Unani, and siddha.In india it is reported that traditional healers use 2500 plant species and 1000 species of plants serve as regular source of medicine.

India is rich in its tribal population from the immemorial time with their traditional knowledge system which deals with the many significant aspects and the health issues of tribal communities. The tribal people get their cure with the help of their traditional knowledge and understanding of nature and local practitioners and own herbal home work.

The use of herbal medicine by tribal communities by district socio-cultural practices, religious, beliefs supports of the traditional ability and traditional medicine men.These people are called by different names of their profesional identity as Nativaidyas, Panditha, gida-moo like panditha, alalekai panditha, hallividya etc.,

\section{MATERIALS AND METHODS}

Study area

To make the study more comprehensive five different study area are selected in five different directions of taluk accordingly chitradurga is one of the central districts of Karnataka state with much racial sociocultral diversity Chitradurga district lies between longitude $76^{0} .24$ and latitude $14{ }^{0} 14$ and elevation 732 above the sea level. Periodic fields survey were carried out in Chitradurga taluk to collect data of the tribal people. (Bedas, Gollas, besthas, Lambanis, Hakki pikki) local vaidyas villege elders and native medicine men through personal communication using questionarie our questionarie allowed descriptive response on the plant prescribed part used, medicinal uses, mode of prepartions like decoction paste powder tablet and etc.

\section{ETANOMEDICINAL SURVEY}

frequent field visit were conducted in 10-15 randomly selected villages namely Haliyuru, Thirumalapura, Jankonda ganjigattae, madakaripura, Madanayakanahally, Siddapura and many other places etc.,

Ethanobotanical explorations were undertaken during 201718.The informations on the herbal medicine used against many disease through repeated interviews and discussions using a questionnarie prepared according WHO questionnarie model (sinha 1996) with the people who are [practising the local cure system and also the people who are using it .Now a days studies on herbal medicine are given top priority. People are slowly awakeing about the dangerous side affects of the allopathic medicine are the turing towards the so called neglated backyard plants for curing many of their aliments in this context the preliminary study carried out chitradurga taluk reveals that the people who are living in rural areas are still using these herbal drug effectively against many of problems even in those time of sophisticated modern medicine. 
International Journal of Engineering Applied Sciences and Technology, 2019

Vol. 4, Issue 3, ISSN No. 2455-2143, Pages 541-552

Published Online July 2019 in IJEAST (http://www.ijeast.com)

\section{RESULT AND DISCUSSION}

\begin{tabular}{|c|c|c|c|c|c|c|}
\hline Sl.no & Ailments & Botanical name & Common name & Family & Part used & $\begin{array}{c}\text { Mode of } \\
\text { preparation } \\
\text { administration } \\
\text { dosage }\end{array}$ \\
\hline \multirow[t]{7}{*}{1} & Fever & Andrographis paniculta & Nelabevu & Acanthaceae & Leaves & $\begin{array}{c}\text { Leaves of these } \\
\text { plant with equal } \\
\text { quantity and each } \\
\text { are finely } \\
\text { Powdered and } \\
\text { boiled in a litre of } \\
\text { water with sugar } \\
\text { and honey divided } \\
\text { into three parts and } \\
\text { taken orally as } \\
\text { thrice a day for 3-4 } \\
\text { days }\end{array}$ \\
\hline & & Tinospora cardifolia & Amruthaballi & Menispermaceae & Leaves & Same \\
\hline & & Ocimum santalum & Tulsi & Lamiaceae & Leaves & $\begin{array}{l}\text { The leaves of the } \\
\text { plant and adding } \\
\text { 10g trikaru } \\
\text { (Zingiber } \\
\text { officinalis,piper } \\
\text { nigrum,piper } \\
\text { longum) are } \\
\text { crushed made into } \\
\text { tablets taken orally } \\
\text { thrice a day till cure }\end{array}$ \\
\hline & & Zingiber officinalis & Shunti & Zingiberaceae & $\begin{array}{l}\text { Rhizo } \\
\text { me }\end{array}$ & \\
\hline & & & & Piperaceae & Fruit & \\
\hline & & & & Piper nigrum & Mensu & \\
\hline & & & & Piper longum & Hippali & \\
\hline 2 & $\begin{array}{c}\text { Diarrhea } \\
\text { amashankae }\end{array}$ & Cyanodondactylon & Garikehulu & poaceae & Leaves & $\begin{array}{c}\text { Leaves of } \\
\text { cynodondactylon } \\
\text { and } \\
\text { aeglemormelosand } \\
\text { ginger and } \\
\text { foeniculumvulgarea } \\
\text { re crushed are }\end{array}$ \\
\hline
\end{tabular}


International Journal of Engineering Applied Sciences and Technology, 2019

Vol. 4, Issue 3, ISSN No. 2455-2143, Pages 541-552

Published Online July 2019 in IJEAST (http://www.ijeast.com)

\begin{tabular}{|c|c|c|c|c|c|c|}
\hline & & & & & & $\begin{array}{l}\text { boiled in } 200 \mathrm{ml} \text { of } \\
\text { water to prepare } \\
\text { decotion and taken } \\
\text { oralluy } 2-3 \text { times } \\
\text { per day for } 4 \text { days }\end{array}$ \\
\hline & & Zingiberofficinalis & Shunti & Zingiberaceae & Rhizome & \\
\hline & & Foeniculumvulgare & soompu & Apiaceae & Fruit & \\
\hline & & Aegalemarmelous & Bilwapatre & Rutaceae & Fruits & $\begin{array}{l}\text { Fruits are boiled } \\
\text { the inner pulp is } \\
\text { mixed with } \\
\text { jiggery,taken orally } \\
\text { twice a day until } \\
\text { cure }\end{array}$ \\
\hline \multirow[t]{5}{*}{3} & Piles & Achyranthusaspera & Utrani & Amarantahceae & Root & $\begin{array}{l}\text { All the three with } \\
\text { equal quantity are } \\
\text { taken and crushed } \\
\text { boiled in water to } \\
\text { make decotion } \\
\text { taken orally twice a } \\
\text { day early in the } \\
\text { morning for a week }\end{array}$ \\
\hline & & Aspargus racemosus & Shatavari & liliaceae & Root & \\
\hline & & Adathodazeylanica & Aadusogae & Acanthaceae & Root & \\
\hline & & Plumbagozeylanioa & Chitramool & Plumbaginaceae & Root & $\begin{array}{l}\text { Root paste is mixed } \\
\text { with lemon juice } \\
\text { applied on the } \\
\text { affected region for } \\
\text { one week }\end{array}$ \\
\hline & & Citrus limon & Lemon & Rutaceae & Fruit juice & \\
\hline \multirow[t]{2}{*}{4} & $\begin{array}{c}\text { Back } \\
\text { pain/chestpain/abo } \\
\text { dmen pain }\end{array}$ & Jatropa curcus & Kadu oudalmara & Euphorbiaceae & Root & $\begin{array}{l}\text { Root of the two } \\
\text { plants are taken in } \\
\text { equal amount and } \\
\text { crushed to make } \\
\text { decotion and taken } \\
\text { orallyfor 2- } \\
\text { 3days }\end{array}$ \\
\hline & & Rauwolfia serpentine & Sarpagandhi & Apocyanaceae & Root & \\
\hline
\end{tabular}


International Journal of Engineering Applied Sciences and Technology, 2019

Vol. 4, Issue 3, ISSN No. 2455-2143, Pages 541-552

Published Online July 2019 in IJEAST (http://www.ijeast.com)

\begin{tabular}{|c|c|c|c|c|c|c|}
\hline & & Casealpiniabonduc & Gajjaga & Casalpinaceae & Leaves & $\begin{array}{l}\text { Leaf extract is } \\
\text { made into decotion } \\
\text { and taken orally for } \\
\text { a week ,twice a day }\end{array}$ \\
\hline 5 & Cold & Argmone mexicana & Datturi & papaveraceae & Stem & $\begin{array}{c}\text { Extract of stem } \\
\text { taken orally with } \\
\text { hot water for only } \\
\text { one time }\end{array}$ \\
\hline \multirow[t]{6}{*}{6} & Cough & Pongamia pinnata & Hongaemara & Fabaceae & Leaves & $\begin{array}{l}\text { Leaf extract is } \\
\text { mixed with powder } \\
\text { of piper nigrum and } \\
\text { taken orally early in } \\
\text { the morning for a } \\
\text { week. }\end{array}$ \\
\hline & & Piper nigrum & Mensu & Piperaceae & Fruit & \\
\hline & & Calotropis procera & Bili eke & Asclepiadaceae & Root & $\begin{array}{l}\text { Root bark is shade } \\
\text { dried and } \\
\text { powdereed and } \\
\text { stored then } 2 \mathrm{~g} \text { of } \\
\text { powder is mixed } \\
\text { with one spoon of } \\
\text { honey taken orally } \\
\text { twice a day for 2- } \\
\text { 3weeks }\end{array}$ \\
\hline & & Centella asiatica & Ondelaga & Apiaceae & Leaves & $\begin{array}{l}12 \mathrm{~g} \text { of leaves and } \\
3 \mathrm{~g} \text { of piper nigrum } \\
\text { are crushed and } \\
\text { leaves it for boiled } \\
\text { in } 1 / 2 \text { litre water } \\
\text { until the water } \\
\text { reducesto } 125 \mathrm{ml} \\
\text { and it is filtered } \\
\text { taken orally twice a } \\
\text { day for a week }\end{array}$ \\
\hline & & Piper nigrum & Menasu & Piperacea & Fruits & \\
\hline & & Semecarpus anacardium & Gerubeeja & Anacardiaceae & $\begin{array}{l}\text { Latex of } \\
\text { fuit }\end{array}$ & $\begin{array}{l}\text { Latex of fruits is } \\
\text { taken on the finer } \\
\text { tip and applied on } \\
\text { ulva for } 2-3 \text { days }\end{array}$ \\
\hline \multirow[t]{2}{*}{7} & $\begin{array}{l}\text { Asthama } \\
\text { (Dhammu, }\end{array}$ & Argemone mexicana & datturi & papaveraceae & $\begin{array}{l}\text { Whole } \\
\text { plant }\end{array}$ & $\begin{array}{l}\text { Plant is driewd and } \\
\text { powdered and } \\
\text { smooked until cure }\end{array}$ \\
\hline & & Calotropis procera & Bili eke & Asclepidaceae & Leaves & $\begin{array}{c}\text { The leaves are } \\
\text { burnt and powdered }\end{array}$ \\
\hline
\end{tabular}


International Journal of Engineering Applied Sciences and Technology, 2019

Vol. 4, Issue 3, ISSN No. 2455-2143, Pages 541-552

Published Online July 2019 in IJEAST (http://www.ijeast.com)

\begin{tabular}{|c|c|c|c|c|c|c|}
\hline & & & & & & $\begin{array}{l}\text { and mixed with } \\
\text { honey and taken } \\
\text { orally twice in a } \\
\text { day for 2-3 weeks } \\
\text { in young twig is } \\
\text { taken orally with } \\
\text { piper beetle leaf for } \\
40 \text { days }\end{array}$ \\
\hline & & Piper beetle & Villedele & Piperaceae & Leaves & \\
\hline & & Ficus religiousa & Aralimara & Moracreace & Seeds & $\begin{array}{l}\text { Sun dried seed } \\
\text { powder of plant is } \\
\text { taken orally along } \\
\text { with cold water } \\
\text { thrice a day for 20- } \\
40 \text { days } \\
\end{array}$ \\
\hline & & Limonia acidissima & Beladamara & Rutaceae & Fruit & $\begin{array}{l}\text { Fruit pulp of the } \\
\text { plant is mixed with } \\
\text { the fine seed } \\
\text { powder of } \\
\text { terminaliabellaricaa } \\
\text { nd taken orally } \\
\text { twice a day for 3-4 } \\
\text { days }\end{array}$ \\
\hline & & Cassia fistula & Kakkaegida & Caesalpinaceae & $\begin{array}{c}\text { Fruits/leav } \\
\text { es }\end{array}$ & $\begin{array}{l}\text { The powder dried } \\
\text { leaves are filled } \\
\text { with the seed } \\
\text { removing the fruit } \\
\text { pulp c fistula then } \\
\text { is lightening used } \\
\text { as cigarette the } \\
\text { smoking is } \\
\text { continued till cured }\end{array}$ \\
\hline \multirow[t]{3}{*}{8} & Hiccups (bikkalike & Tamarindus indica & Hunsae & Caesalpinaceae & Leaves & $\begin{array}{l}\text { The cleaned leaves } \\
\text { of the plant are } \\
\text { squeezed and 3-4 } \\
\text { drops of that extract } \\
\text { administered into } \\
\text { the nose twice a } \\
\text { day for 1-2 days. }\end{array}$ \\
\hline & & Limoniaacidissima & Beladamara & Rutaceae & Leaves & $\begin{array}{l}20 \mathrm{~g} \text { of leaf extract } \\
\text { of plant is mixed } \\
\text { with fine powder } \\
\text { terminaliabellarica } \\
\text { and } 50 \mathrm{ml} \text { of honey } \\
\text { taken orally twice a } \\
\text { day for 2-30days }\end{array}$ \\
\hline & & Ficusbenghalensis & Aaladamara & moraceae & Fruits & 4-5 fresh fuits are \\
\hline
\end{tabular}


International Journal of Engineering Applied Sciences and Technology, 2019

Vol. 4, Issue 3, ISSN No. 2455-2143, Pages 541-552

Published Online July 2019 in IJEAST (http://www.ijeast.com)

\begin{tabular}{|c|c|c|c|c|c|c|}
\hline & & & & & & $\begin{array}{l}\text { crushed and with } \\
\text { honey and taken } \\
\text { orally twice a day } \\
\text { for 2-4days } \\
\end{array}$ \\
\hline 9 & helmenthiasis & Mangiferaindica & Mavinamara & Anacardiaceae & Seeds & $\begin{array}{l}\text { Fine seed powderof } \\
\text { the plant will be } \\
\text { taken orally early in } \\
\text { the morning for } \\
\text { four days on } 5 \text { days } \\
\text { castor oil will be } \\
\text { taken orallyin the } \\
\text { morning }\end{array}$ \\
\hline \multirow[t]{2}{*}{10} & $\begin{array}{c}\text { Lice } \\
\text { (thaleyahenu) }\end{array}$ & Azardirachta indica & Bevinamara & Meliaceae & Seeds & $\begin{array}{l}\text { Seeds are crushed } \\
\text { with cow's urine } \\
\text { and applied to scalp } \\
\text { before the morning } \\
\text { bath for one week }\end{array}$ \\
\hline & & Aeglemormelous & Bilwapatre & Rutaceae & Root & $\begin{array}{l}\text { Root is crushed } \\
\text { with cow's urine } \\
\text { and applied to } \\
\text { heads before two } \\
\text { hours at morning } \\
\text { bath for one week }\end{array}$ \\
\hline \multirow[t]{2}{*}{11} & Jaundice & Lawsonia inermis & Madarangigoranti & Lythraceae & Leaves & $\begin{array}{l}24 \mathrm{~g} \text { of leaves are } \\
\text { crushed with } 200 \mathrm{ml} \\
\text { of cow milk and } \\
\text { taken orally in the } \\
\text { morning for } 1-2 \\
\text { weeks }\end{array}$ \\
\hline & & Phyllanthusamaus & Nelanelli & Euphorbiaceae & Leaves & $\begin{array}{l}\text { The leaves crushed } \\
\text { and mixed with } \\
\text { cows milk and } \\
\text { taken orally in the } \\
\text { morning for 1-2 } \\
\text { weeks. }\end{array}$ \\
\hline \multirow[t]{2}{*}{12} & Tuberculosis & Adathodazeylanica & Aadusogae & Acanthaceae & Leaves & $\begin{array}{l}60 \mathrm{ml} \text { of the extract } \\
\text { is mixed with } 30 \mathrm{ml} \\
\text { of honey taken } \\
\text { orally twice a day } \\
\text { for } 21-40 \text { days }\end{array}$ \\
\hline & & Withaniasomnifera & Ashwagandha & Solanaceae & Leaves & $\begin{array}{l}\text { Both the leaves of } \\
\text { the plant are made } \\
\text { into fine powdered } \\
\text { and mixed with } \\
\text { into the equal } \\
\text { amount of water } \\
\text { and milk to prepare }\end{array}$ \\
\hline
\end{tabular}


International Journal of Engineering Applied Sciences and Technology, 2019

Vol. 4, Issue 3, ISSN No. 2455-2143, Pages 541-552

Published Online July 2019 in IJEAST (http://www.ijeast.com)

\begin{tabular}{|c|c|c|c|c|c|c|}
\hline & & & & & & $\begin{array}{l}\text { decoction,taken } \\
\text { orally thrice a day } \\
\text { for } 1-2 \text { months }\end{array}$ \\
\hline & & Tinosporacardifolia & Amruthaballi & Menispermaceae & Leaves & \\
\hline & & Tamarindusindica & Hunasemara & Caesalpinaceae & Stem & $\begin{array}{l}\text { The bark is made } \\
\text { into ash mixed with } \\
\text { cold water taken } \\
\text { orally twice a day } \\
\text { for } 40 \text { days }\end{array}$ \\
\hline \multirow[t]{3}{*}{13} & Heart disease & Beuteamonosperma & Muthugadamara & Fabaceae & Seeds & $\begin{array}{l}\text { Seeds are crushed } \\
\text { in lemon extract } \\
\text { and made into } \\
\text { small pills taken } \\
\text { orally early in the } \\
\text { morning for three } \\
\text { days } \\
\end{array}$ \\
\hline & & Centellaasiatica & Ondelaga & Apiaceae & Leaves & $\begin{array}{l}\text { Both these plant } \\
\text { leaves are finely } \\
\text { powdered equally } \\
\text { and mixed with } \\
250 \mathrm{ml} \text { of water to } \\
\text { prepare.decoction } \\
\text { taken orally twice } \\
\text { a day for 2- } \\
\text { 3months }\end{array}$ \\
\hline & & Tinosporacardifolia & Amruthaballi & Menispermaceae & Leaves & \\
\hline \multirow[t]{3}{*}{14} & Buring urination & Argemonemexicana & Datturi & papaveraceae & Leaves & $\begin{array}{l}10 \text { drops of leaf } \\
\text { extract is mixed } \\
\text { with } 100 \mathrm{ml} \text { of curd } \\
\text { taken orally early in } \\
\text { the morning for } 7 \\
\text { days }\end{array}$ \\
\hline & & Ficusracemosa & Attimara & Moraceae & Latex & $\begin{array}{l}\text { Latex of the tree } \\
100 \mathrm{ml} \text { is mixed } \\
\text { with } \\
\text { cuminumcyminum } \\
\text { taken orally early in } \\
\text { the morning for one } \\
\text { week. }\end{array}$ \\
\hline & & Cuminumcyminum & Jeera & Apiaceae & Seeds & \\
\hline 15 & Kidney stone & Achyanthusaspera & Utrani & Amaranthaceae & Root & $\begin{array}{l}\text { Root of the plant is } \\
\text { dried and finely } \\
\text { powdered and is } \\
\text { taken orally early in } \\
\text { thre morning for 2- }\end{array}$ \\
\hline
\end{tabular}


International Journal of Engineering Applied Sciences and Technology, 2019

Vol. 4, Issue 3, ISSN No. 2455-2143, Pages 541-552

Published Online July 2019 in IJEAST (http://www.ijeast.com)

\begin{tabular}{|c|c|c|c|c|c|c|}
\hline & & & & & & 3 weeks. \\
\hline & & Tephrosiapurpurea & Adavihurali & Fabaceae & Seeds & $\begin{array}{l}\text { Seed mixed with } \\
\text { water boiled and } \\
\text { filtered to that add } \\
\text { goat milk taken } \\
\text { orally twice a day } \\
\text { for } 1-2 \text { weeks. }\end{array}$ \\
\hline \multirow[t]{4}{*}{16} & $\begin{array}{c}\text { Haematuria } \\
\text { (rakthamootra ) }\end{array}$ & Phyllanthusamarus & Nelanelli & Euphorbiaceae & $\begin{array}{l}\text { Whole } \\
\text { plant }\end{array}$ & $\begin{array}{l}\text { Whole plant and } \\
\text { cuminumcyminum } \\
\text { is crushed with } \\
\text { buffalo butter milk } \\
\text { filtered taken orally } \\
\text { alomg with buffalo } \\
\text { butter milk early } \\
\text { for 1-2 weeks. }\end{array}$ \\
\hline & & Ficusracemosa & Attimara & Moraceae & Fruit & $\begin{array}{l}\text { 4-60fruits taken } \\
\text { orally along with } \\
\text { the honey twice a } \\
\text { day for } 1-2 \text { weeks }\end{array}$ \\
\hline & & Cynodondactylon & Garikaehullu & Poaceae & Leaves & $\begin{array}{c}\text { Leaf extract and } \\
\text { stone sugar and } \\
\text { seed powder of } \\
\text { syzigiumaromaticu } \\
\text { m mixed } \\
\text { thoroughly taken } \\
\text { twice day for 1- } \\
2 \text { weeks } \\
\end{array}$ \\
\hline & & Syzigiumaromaticum & Lavanga & Mythraceae & $\begin{array}{l}\text { Unopened } \\
\text { flower } \\
\text { buds }\end{array}$ & \\
\hline \multirow[t]{4}{*}{17} & Diabetes & Ficusracemosa & Attimara & Moraceae & Stem bark & $\begin{array}{c}\text { Shade dried bark } \\
\text { ismixed with water } \\
\text { to prepare } \\
\text { decoction taken } \\
\text { orally twice in a } \\
\text { day for } 7-14 \text { days. }\end{array}$ \\
\hline & & Aeglemormelous & Bilwapatre & rutaceae & $\begin{array}{l}\text { Leaf } \\
\text { extract }\end{array}$ & $\begin{array}{l}\text { Leaf extract is } \\
\text { taken orally twice a } \\
\text { ady until cured }\end{array}$ \\
\hline & & Pterocarpousmarsupium & Raktha hone & Fabaceae & Bark & $\begin{array}{l}\text { Bark is finely } \\
\text { powdered is ,mixed } \\
\text { with water taken } \\
\text { orally } 4 \text { times per } \\
\text { day until cure }\end{array}$ \\
\hline & & Phyllanthusemblica & Bettadanelli & Euphorbiaceae & Fruit & Fruits are taken \\
\hline
\end{tabular}


International Journal of Engineering Applied Sciences and Technology, 2019

Vol. 4, Issue 3, ISSN No. 2455-2143, Pages 541-552

Published Online July 2019 in IJEAST (http://www.ijeast.com)

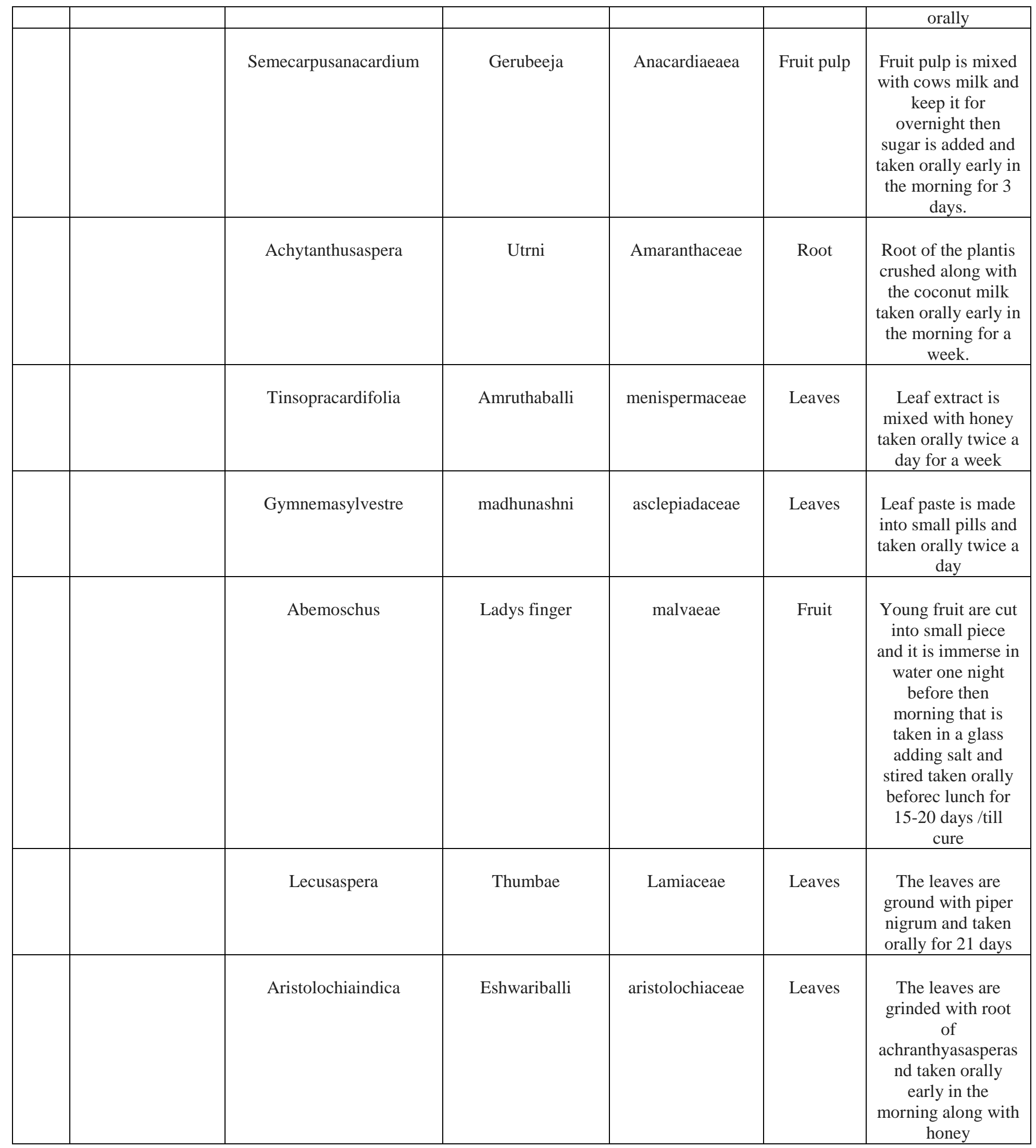


International Journal of Engineering Applied Sciences and Technology, 2019

Vol. 4, Issue 3, ISSN No. 2455-2143, Pages 541-552

Published Online July 2019 in IJEAST (http://www.ijeast.com)

\begin{tabular}{|c|c|c|c|c|c|c|}
\hline \multirow[t]{5}{*}{18} & Leprosy & Calotropisprocera & bilieke & ascelepidaceae & Root & $\begin{array}{l}\text { The root is made } \\
\text { into paste along } \\
\text { with cows urine is } \\
\text { applied to affected } \\
\text { part until cure }\end{array}$ \\
\hline & & Azardirachtaindica & Bevinamara & meliaceae & Leaves & $\begin{array}{l}\text { Leaf extract is } \\
\text { taken orally along } \\
\text { with cows urine } \\
\text { twice a day until } \\
\text { cure }\end{array}$ \\
\hline & & Tinsoporacordifolia & Amruthaballi & menispermaceae & $\begin{array}{l}\text { Whole } \\
\text { plant }\end{array}$ & $\begin{array}{l}\text { Plant juice is taken } \\
\text { orally twice a day } \\
\text { for 3-4 months }\end{array}$ \\
\hline & & Abrusprecatorius & Gulaganji & fabaceae & Seeds & $\begin{array}{c}\text { The seeds of } \\
\text { abrusprecatorius } \\
\text { and } \\
\text { plumbagozeylanica } \\
\text { root } \\
\text { semicarpousanacar } \\
\text { dium seed and } \\
\text { azardirachtaindica } \\
\text { leaves are taken in } \\
\text { equal amount and } \\
\text { make it fine paste } \\
\text { and applied on } \\
\text { affected region } \\
\text { until the cure. }\end{array}$ \\
\hline & & Plumbagozeylanoica & Chitramola & plumbaginaceae & Root & \\
\hline & & Semecarpousanacardium & Gerubeeja & anacardiaceae & Seed & \\
\hline & & Azardirachtaindica & Bevinamara & meliaceae & Leaves & \\
\hline 19 & Sinus & Mimosa pudica & Muttidare muni & Mimosaceae & $\begin{array}{l}\text { Whole } \\
\text { plant }\end{array}$ & $\begin{array}{l}\text { Plant paste is } \\
\text { applied on affected } \\
\text { region until cure }\end{array}$ \\
\hline \multirow[t]{2}{*}{20} & Pimples /acne & Ocimumbasilicum & Kama kasthuri & lamiaceae & $\begin{array}{l}\text { Leaf } \\
\text { extract }\end{array}$ & $\begin{array}{l}\text { Laef extract is } \\
\text { applied on whole } \\
\text { face }\end{array}$ \\
\hline & & Caesalpiniabondu & Gajjuga & caesalpinaceae & Root & $\begin{array}{c}\text { Root paste is } \\
\text { applied on pimples } \\
\text { until cure }\end{array}$ \\
\hline 21 & Chicken fox & Adathodazeylanica & Adusogae & acanthaceae & Leaves & $\begin{array}{l}\text { Leaves extract and } \\
\text { honey mixed and } \\
\text { taken orally twice a } \\
\text { day for 8-10 days }\end{array}$ \\
\hline
\end{tabular}


International Journal of Engineering Applied Sciences and Technology, 2019

Vol. 4, Issue 3, ISSN No. 2455-2143, Pages 541-552

Published Online July 2019 in IJEAST (http://www.ijeast.com)

\begin{tabular}{|c|c|c|c|c|c|c|}
\hline & & Azardirachtaindica & Bevinamara & meliaceae & Leaves & $\begin{array}{l}\text { Leaf paste is } \\
\text { applied all over the } \\
\text { body leave it for } 30 \\
\text { min and take bath. }\end{array}$ \\
\hline \multirow[t]{2}{*}{22} & Hair fall & Semecarpousanacardium & Gerubeeja & anacardicaeae & Seeds & $\begin{array}{l}1-20 \text { seeds are } \\
\text { boiled in linseed } \\
\text { oil and then seeds } \\
\text { are removed and } \\
\text { applied to the hair }\end{array}$ \\
\hline & & Alternanther a sessilis & Honagannae & amaranthaceae & Leaves & $\begin{array}{l}\text { Leaf extract cows } \\
\text { milk lin seed } \\
\text { ioltaken in equal } \\
\text { amount mixed and } \\
\text { applied to the hair. }\end{array}$ \\
\hline \multirow[t]{2}{*}{23} & Ear disease & Calotropisprocera & Bili eke & asclepidaceae & Leaves & $\begin{array}{l}\text { Leaf is burnt and } \\
\text { crushed to make } \\
\text { extract and then it } \\
\text { is dropped into the } \\
\text { ear daily twice }\end{array}$ \\
\hline & & Limoniaacidissina & Beladamara & rutaceae & Bark & $\begin{array}{l}\text { Bark extract is } \\
\text { mixed with honey } \\
\text { and dropped into } \\
\text { the ear daily twice }\end{array}$ \\
\hline \multirow[t]{2}{*}{24} & Eye disorder & Rauvolfiaserpentina & Sarpagandhi & apocyanace & Leaves & $\begin{array}{l}\text { Leaf extract is used } \\
\text { as eye drops 3-4 } \\
\text { drops per day once } \\
\text { in a day for a week }\end{array}$ \\
\hline & & Beuteamonosperma & Muthuga & fabaceae & Seeds & $\begin{array}{l}\text { Seeds are fried in } \\
\text { ghee and crushed } \\
\text { finely and applied } \\
\text { into the eyes }\end{array}$ \\
\hline 25 & Fertility & Aristolochiabracteolata & Kattekirubanasoppu & Aristalochiaceae & Leaves & $\begin{array}{l}\text { Leaves are crushed } \\
\text { into pepper and } \\
\text { garlic made into } 9 \\
\text { tablets taken orally } \\
\text { once in a day upto } \\
\text { to } 9 \text { days taken } \\
\text { during peroids time } \\
\text { without take bath }\end{array}$ \\
\hline
\end{tabular}

\section{REFERENCES}

1. Bhatta,D.c., K.D. Mitaliya,M.A.Nurani and U.S. Baxi (2000).the herbal treatment for controlling diabeties. Ad. Plant sci.12(11):339-342)
2. Prashanth kumar $P$ and VIdyasagar $G \quad M$ Documentation of traditional knowledge on Medicinal plant of Bidar District Karnataka Vol 5 (3) (2006) (pp 295-225) 
3. H.M.prakasha and M. krishnappahrerbal folk medicine used against cardiovascular and dental problems in N.R.PURA TALUK,KARNATAKAad.plant sci.(19(1)203208),(2006)

4. $\mathrm{H}$.M .prakasha and $\mathrm{M}$ krishanappa people knowledge on medicinal plants in sringeritaluk, Karnataka vol.5(3) july (2006),(pp.353-357.)

5. Hmprakasha,Mkrishanappa ,YL krishanamurthy folk medicine of NR PURA TALUK IN Chimagalur district of Karnataka vol.9(1) January (2010) (pp.5560)

6. B E Van Wyk ,H.de wet, F. R. Van Heerden An ethanobotanical survey of medicinal plants in the southeasternkaroo, south Africa 74(2008) (696-704)

7. P Tamulli and P Sharma Ethno Medico Botany of the Dimasa Kachari of North Cachar hills District of Assam Vol 9 (4) (2010) (pp 718-720)

8. MuniappanAyyanar savarimuthuIgnacimuthuEthanobotanical survey of medicinal plants commonly used by kanitribalsinTirunelveli hills of western ghatsindia 134(2011)(851-864)

9. Kulkarni C.G and Deshpande Adwait (2011) Folk therapies of Katakaris from Maharashtra Vol 10 (3) (pp 554-558) 